\title{
Seismisitas di Wilayah Jawa Tengah dan Sekitarnya Berdasarkan Hasil Relokasi Hiposenter dari Empat Jaringan Seismik Menggunakan Model Kecepatan 3-D
}

\author{
Seismicity in Central Java Area and Its Surroundings Based on \\ the Hypocenter Relocation Results from Four Seismic Networks \\ Using a 3-D Velocity Model
}

\author{
Mohamad Ramdhan*, Priyobudi, Said Kristyawan, Andry Syaly Sembiring \\ Badan Meteorologi, Klimatologi, dan Geofisika (BMKG) \\ Jl. Angkasa 1 No. 2 Kemayoran, Jakarta, Indonesia, 10720 \\ *E-mail: mohamad.ramdhan@bmkg.go.id; mramdhan123@gmail.com
}

Naskah diterima: 12 Maret 2020, direvisi: 28 April 2020, disetujui: 2 Mei 2020

DOI: $10.17146 /$ eksplorium.2020.41.1.5828

\begin{abstract}
ABSTRAK
Relokasi hiposenter merupakan suatu metode yang digunakan untuk mendapatkan parameter-parameter gempa yang presisi. Parameter-parameter tersebut digunakan untuk studi tektonik lanjut seperti seismic hazard assessment pada suatu area. Penggunan model kecepatan 3-D secara teori akan memberikan hasil yang lebih baik dibandingkan dengan model 1-D karena model kecepatan di bawah permukaan bumi lebih mendekati model 3-D. Sebanyak 767 event gempa yang direkam oleh jaringan seismik DOMERAPI, MERAMEX, BMKG, dan BPPTKG digunakan pada penelitian ini. Gempa-gempa tersebut direlokasi dengan model kecepatan 3-D dan dianalisis untuk studi seismotektonik di wilayah Jawa Tengah dan sekitarnya. Hasil relokasi hiposenter menggunakan model kecepatan 3-D berhasil mendeteksi sejumlah fitur tektonik secara lebih jelas seperti struktur kolom yang berkaitan dengan Struktur backthrust di selatan Kebumen. Penampang vertikal arah barat-timur yang melewati Sesar Opak mengindikasikan arah dip bidang sesarnya ke arah timur. Zona seismik ganda yang terdeteksi pada studi sebelumnya tidak bisa teridentifikasi dengan baik pada studi ini. Sejumlah gempa volcanotectonic (VT) berkaitan dengan aktivitas magma dangkal Gunung Merapi terdeteksi juga dengan jelas pada studi ini.
\end{abstract}

Kata kunci: Gempa, relokasi, kecepatan 3-D, Jawa Tengah.

\begin{abstract}
Hypocenter relocation is a method used to get precise earthquake parameters. They will be useful for an advanced tectonic study like seismic hazard assessment in an area. The hypocenter relocation using a 3-D velocity model will theoretically obtain better results than a 1-D velocity model because the earth subsurface model is closed with a 3-D model. Some 767 earthquakes recorded by DOMERAPI, MERAMEX, BMKG, and BPPTKG networks used in this research. They were relocated by using a 3-D velocity model and analyzed for seismotectonic study in Central Java area and its surroundings. The result of hypocenter relocation using a 3-D velocity model is successfully detecting some tectonic features more clearly like columnar structure related to the backthrust structure at the south of Kebumen. The west-east vertical cross-section crossing the Opak fault indicates the dip of the fault plane is directing to the east. This study could not identify the double seismic zone, which was detected by the previous research. Some volcano-tectonic (VT) earthquakes related to the shallow magma activity of Mount Merapi also are detected clearly in this study.
\end{abstract}

Keywords: earthquake, relocation, 3-D velocity, Central Java. 


\section{PENDAHULUAN}

Area Jawa Tengah dan sekitarnya merupakan wilayah yang memiliki tingkat aktivitas kegempaan tinggi baik di wilayah darat maupun laut. Gempa Yogyakarta tahun 2006 merupakan contoh gempa yang mengakibatkan banyak korban jiwa dan kerusakan masif infrastruktur. Pengetahuan tentang kondisi tektonik di wilayah tersebut sangat berguna untuk mitigasi bencana gempa sehingga jika gempa besar melanda area tersebut jumlah korban jiwa bisa diminimalkan. Selain itu, mitigasi bencana juga sangat penting di dalam perencanaan pembangunan sarana vital seperti bandara, industri, dan reaktor nuklir. Studi seismisitas dari katalog gempa yang sudah terelokasi hiposenternya bisa digunakan untuk memahami kondisi tektonik di suatu wilayah sebagaimana telah dilakukan dalam sejumlah penelitian terdahulu di wilayah Sumatera, Jawa, dan Papua [1-4]. Studi tersebut telah berhasil menjelaskan karakteristik kegempaan yang berada di masing-masing wilayah penelitiannya.

Fitur tektonik zona seismik ganda di selatan Jawa Tengah merupakan salah satu fitur yang berhasil dideteksi dan dijelaskan dari studi seismisitas di wilayah tersebut dengan menggunakan jaringan seismik MERapi Amphibious EXperiment (MERAMEX) [5]. Gempa-gempa yang direkam oleh jaringan seismik tersebut digunakan untuk studi tomografi seismik waktu tempuh di Wilayah Jawa Tengah dan sekitarnya. Hubungan antara zona subduksi dan busur pegunungan dapat dijelaskan dengan baik dari studi tersebut. Citra tomogram dari studi tersebut memperlihatkan naiknya material berkecepatan rendah dari zona subduksi menuju busur pegunungan [57].
Potensi erupsi pada sejumlah gunung api juga menjadi ancaman bencana di wilayah Jawa Tengah dan sekitarnya. Gunung Merapi merupakan salah satu gunung yang paling aktif di area tersebut. Gunung tersebut memiliki periode erupsi relatif pendek antara dua sampai enam tahun seperti yang terjadi pada tahun 1984, 1986, 1992 dan 1994 [8]. Erupsi dengan kekuatan yang jauh lebih besar bisa terjadi dalam periode ulang sekitar 100 tahun seperti yang terjadi pada erupsi tahun 2010 [9]. Tingginya aktivitas erupsi di gunung tersebut menarik para ilmuwan kebumian dari berbagai negara untuk memahami proses yang terjadi, baik di bawah maupun di bagian puncak gunung melalui berbagai pendekatan metode geofisika.

Proyek DOMERAPI merupakan proyek kolaborasi antara ilmuwan Indonesia dan Prancis. Proyek ini dilaksanakan untuk memahami struktur bagian dalam Gunung Merapi dengan citra resolusi tomogram yang lebih tingggi dibandingkan hasil studi proyek MERAMEX [5-7,10]. Jaringan seismik DOMERAPI melingkupi Gunung Merapi dan Merbabu dengan jarak seismometer yang lebih rapat dibandingkan dengan jaringan seismik MERAMEX. Jaringan seismik ini dipasang untuk mendeliniasi sistem magma di bawah Gunung Merapi terutama sistem magma yang tidak bisa terdeliniasi oleh jaringan seismik Balai Penyelidikan dan Pengembangan Teknologi Kebencanaan Geologi (BPPTKG) [11-13]. Mayoritas data gempa yang direkam oleh jaringan seismik DOMERAPI berasal dari gempa-gempa tektonik yang berada di selatan Jawa Tengah. Gempa-gempa tersebut direkam secara simultan dengan jaringan seismik BPPTKG dan jaringan seismik Badan Meteorologi, Klimatologi, dan Geofisika (BMKG). Jaringan seismik BMKG dipasang untuk 
memantau aktivitas gempa tektonik di seluruh wilayah Republik Indonesia. Sementara itu, jaringan seismik BPPTKG dipasang untuk memantau aktivitas seismik di bawah Gunung Merapi.

Gempa-gempa yang direkam oleh jaringan seismik DOMERAPI dan BMKG digunakan untuk menganalisis kondisi seismotektonik di wilayah Jawa Tengah dan sekitarnya [14]. Studi tersebut menggunakan relokasi hiposenter dengan model kecepatan 1-D. Namun, kondisi di bawah permukaan bumi sangat kompleks sehingga model kecepatan 1-D tidak cukup ideal dan akurasinya menjadi rendah. Penelitian ini menggunakan pendekatan model kecepatan 3D dengan tujuan menghasilkan parameter hiposenter yang lebih presisi dibandingkan dengan hasil studi sebelumnya [14]. Hasil katalog gempa yang lebih presisi akan memudahkan proses interpretasi kondisi tektonik di area ini.

\section{DATA DAN METODE}

Beberapa Seismometer jaringan seismik DOMERAPI dipasang secara temporer selama 18 bulan, mulai bulan Oktober 2013 sampai pertengahan April 2015. Jaringan seismik tersebut terdiri dari 46 seismometer broad-band. Seiring berjalannya waktu, tujuh seismometer direlokasi untuk mendapatkan signal to noise ratio (SNR) yang lebih tinggi sehingga jumlah total stasiun seismik yang digunakan pada jaringan tersebut menjadi 53. Jaringan seismik BMKG memiliki spasi jarak antar stasiun seismik sejauh 50-100 km. Jaringan seismik tersebut sangat bermanfaat untuk meminimumkan nilai azimuthal gap dari episenter yang berada di luar jaringan seismik DOMERAPI [15].

Jaringan seismik BMKG yang digunakan pada penelitian ini berjumlah 17. Jumlah event gempa yang direkam jaringan seismik
DOMERAPI dan BMKG pada periode yang sama sebanyak 464 [14], 260 gempa juga terekam oleh jaringan seismik BPPTKG yang terdiri dari 17 stasiun seismik. Gempa yang dicatat oleh jaringan seismik BMKG berjumlah 196 gempa dan periode katalog gempanya dari bulan April 2009 sampai bulan Juli 2016. Data katalog gempa BMKG tidak digunakan selama periode perekaman data seismik DOMERAPI karena data waveform jaringan seismik BMKG diproses secara simultan dengan data waveform jaringan seismik DOMERAPI.

Jumlah katalog gempa MERAMEX yang digunakan pada studi ini sebanyak 282 gempa dan direkam oleh 167 stasiun seismik. Jumlah total gempa yang digunakan dari keempat jaringan seismik tersebut sebanyak 942 gempa. Gempa-gempa tersebut digunakan untuk mendeliniasi struktur kecepatan seismik di bawah Gunung Merapi dan Merbabu [12]. Seluruh data gempa direlokasi terlebih dahulu menggunakan metode doubledifference dengan model kecepatan 1-D berdasarkan hasil studi sebelumnya $[5,16$, 17]. Relokasi hiposenter dilakukan untuk mendapatkan parameter hiposenter yang lebih presisi karena perhitungan tomografi seismik waktu tempuh harus menggunakan parameter yang presisi. Parameter hiposenter sendiri merupakan parameter posisi dan kejadian gempa yang terdiri dari longitude $\left(\mathrm{X}_{0}\right)$, latitude $\left(\mathrm{Y}_{0}\right)$, kedalaman $\left(\mathrm{Z}_{0}\right)$ dan waktu kejadian gempa $\left(\mathrm{t}_{0}\right)$. Gambar 1 menunjukkan distribusi seismometer jaringan seismik DOMERAPI, MERAMEX, BMKG dan BPPTKG yang digunakan pada studi ini.

Jumlah data gempa yang digunakan untuk perhitungan tomografi seismik waktu tempuh dan relokasi hiposenter sebanyak 767. Pengurangan data disebabkan oleh adanya parameter hiposenter yang tidak terelokasi dan adanya pembatasaan wilayah untuk 
perhitungan tomografi seismik pada rentang $108^{0}-112^{0}$ BT dan $6^{0}-11^{0}$ LS. Parameter hiposenter yang tidak terelokasi disebabkan oleh data gempa yang tidak fit dengan kriteria parameter yang ditetapkan.

Kriteria data yang digunakan pada penelitian ini dicatat paling sedikit oleh enam stasiun seismik, baik untuk gelombang $\mathrm{P}$ dan $\mathrm{S}$ atau $\mathrm{P}$ saja. Kriteria tersebut dipilih agar perhitungan inversinya over-determined (jumlah data yang digunakan lebih banyak daripada jumlah modelnya). Jumlah total fase yang digunakan pada penelitian ini sebanyak 29.937 (20.185 untuk gelombang P dan 9.752 untuk gelombang $\mathrm{S}$ ). Rasio $\mathrm{Vp} / \mathrm{Vs}$ yang digunakan pada penelitian ini sebesar 1,73 merupakan hasil studi sebelumnya [14]. Gambar 2 menunjukkan sebaran episenter dan titik grid yang berisi nilai model kecepatan seismik.

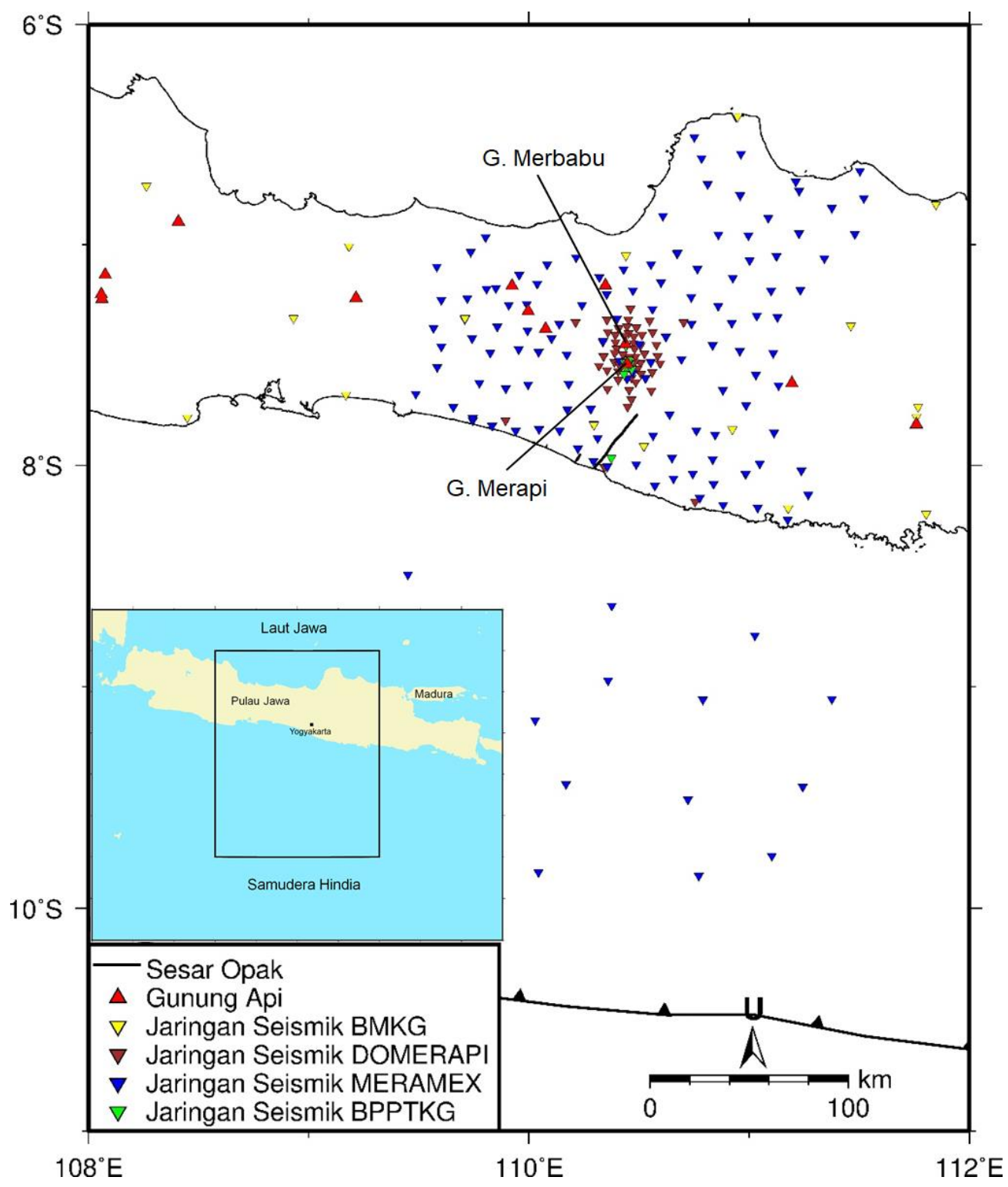

Gambar 1. Sebaran stasiun jaringan seismik DOMERAPI, MERAMEX, BMKG dan BPPTKG di sekitar wilayah Jawa Tengah dan sekitarnya. Kotak hitam pada gambar inset menunjukkan area penelitian pada studi ini. 


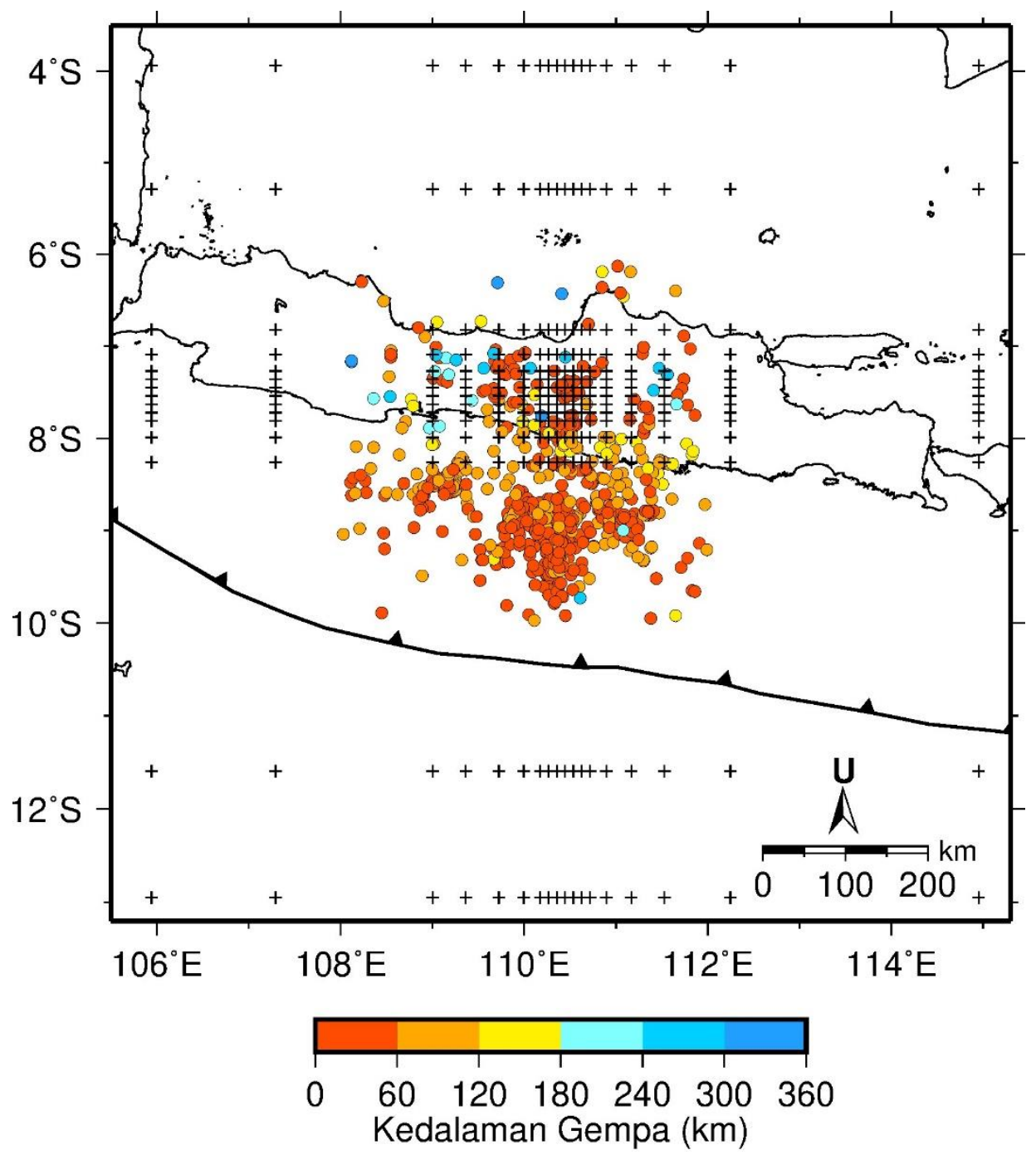

Gambar 2. Sebaran episenter dan grid horisontal dari jaringan seismik DOMERAPI, MERAMEX, BMKG dan BPPTKG di sekitar wilayah Jawa Tengah dan sekitarnya. Distribusi episenter merupakan hasil relokasi hiposenter menggunakan model kecepatan 1-D dengan metode double-difference [16]. Gempa-gempa tersebut digunakan untuk mendeliniasi model kecepatan 3-D di bawah Gunung Merapi dan Merbabu [12].

Perhitungan relokasi hiposenter dengan model kecepatan 3-D pada studi ini menggunakan program SIMULPS12 [18], [19]. Pada program tersebut, parameter hiposenter dan model kecepatan 3-D dihitung secara bersamaan sebagaimana terlihat pada persamaan berikut ini [19].

$r_{i j}=\sum_{k=1}^{3} \frac{\partial T_{i j}}{\partial x_{k}} \Delta x_{k}+\Delta \tau_{i}+\sum_{l=1}^{L} \frac{\partial T_{i j}}{\partial m_{l}} \Delta m_{l}$

Nilai $r_{i j}$ merupakan selisih waktu observasi dan kalkulasi. Waktu observasi merupakan waktu tiba gelombang seismik yang terekam oleh seismometer. Waktu kalkulasi merupakan waktu tiba yang dihitung dari sumber gempa menuju seismometer. Waktu kalkulasi tersebut merupakan fungsi jarak dan kecepatan gelombang seismik yang menjalar melewati interior dalam bumi. Parameter $\Delta x_{k}$ merupakan parameter perubahan posisi sumber gempa yang terdiri dari longitude, latitude dan kedalaman. Nilai $\Delta \tau$ merupakan perubahan parameter waktu kejadian gempa, sedangkan $\Delta m$ merupakan perubahan parameter model kecepatan gelombang seismik yang melewati interior dalam bumi. 
Teknik inversi yang digunakan untuk mendapatkan parameter hiposenter dan kecepatan tersebut menggunakan metode least squares (LSQR) [21].

Jarak antara stasiun pada jaringan seismik DOMERAPI sejauh $\sim 4 \mathrm{~km}$. Jaringan seismik tersebut melingkupi Gunung Merapi dan Merbabu yang menjadi target penelitian proyek tersebut. Struktur kecepatan seismik yang dideliniasi dari keempat jaringan seismik tersebut dapat dilihat dari hasil studi sebelumnya [12]. Sebaran titik grid yang digunakan pada penelitian tidak merata disesuaikan dengan sebaran stasiun seismiknya. Ukuran grid yang lebih kecil di area Gunung Merapi dan Merbabu disebabkan oleh sebaran stasiun seismik yang lebih rapat di kedua area tersebut. Sedangkan di luar kedua area tersebut ukuran gridnya lebih lebar karena jarak antar stasiun seismiknya lebih lebar dan sebaran stasiunnya lebih renggang. Penggunaan ukuran grid yang berbeda sangat berguna untuk menghemat waktu dalam perhitungan parameter hiposenter dan model kecepatan 3-D [20]. Gambar 2 menunjukkan distribusi episenter dan titik grid yang digunakan pada penelitian ini. Jarak dan kedalaman antar grid bisa dilihat pada hasil studi sebelumnya [12].

\section{HASIL DAN PEMBAHASAN}

Root Mean Square (RMS) residual time setelah direlokasi menggunakan model kecepatan 3-D menunjukkan nilai yang mendekati nol jauh lebih banyak dibandingkan dengan menggunakan model kecepatan 1-D sebagaimana ditunjukkan oleh Gambar 3. Nilai RMS residual time yang mendekati nol menunjukkan model kecepatan yang digunakan lebih dekat ke model kecepatan sebenarnya. Namun, model kecepatan sebenarnya tidak pernah diketahui. Model kecepatan hanya bisa didekati dengan menggunakan formulasi matematika tertentu sebagaimana yang dilakukan pada penelitian ini.

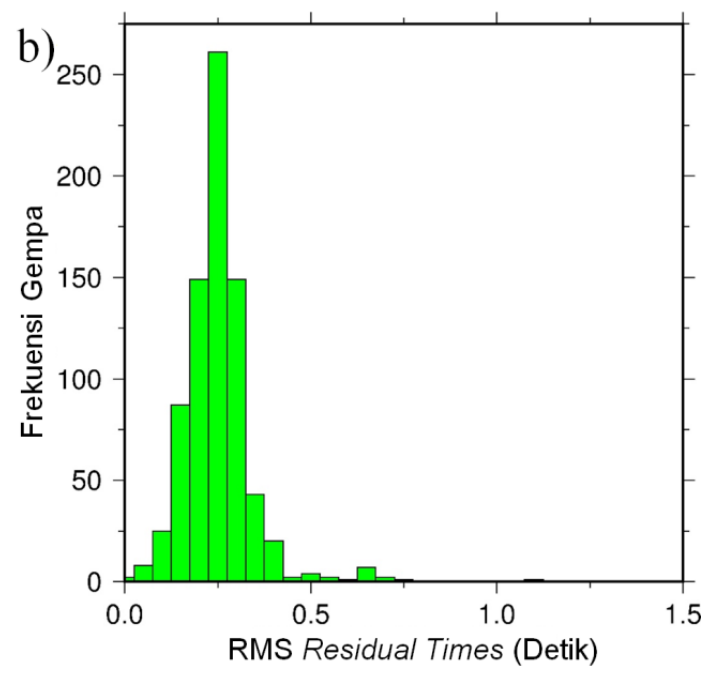

Gambar 3. Distribusi RMS residual time sebelum (a) dan sesudah (b) dilakukan relokasi hiposenter dengan model kecepatan 3-D dari empat jaringan seismik.

Gambar 4 menunjukkan distribusi episenter sebelum dan sesudah dilakukan relokasi hiposenter dengan model kecepatan
3-D. Sedangkan Gambar 5 menunjukkan vektor pergeseran posisi episenter relatif terhadap posisi awal dan diagram mawar 
setelah dilakukan relokasi hiposenter dari Pergeseran episenter ke arah tersebut empat jaringan seismik dengan model kemungkinan besar juga dipengaruhi oleh kecepatan 3-D. Gambar 5 menunjukkan slab yang bergerak ke arah utara searah mayoritas episenter bergerak ke arah utara. dengan gaya tektonik utamanya [22]. RataHal tersebut disebabkan karena mayoritas rata pergeseran episenter sebesar $13 \mathrm{~km}$ dan stasiun berada di Pulau Jawa sedangkan maksimum pergeseran sebesar $83 \mathrm{~km}$ dengan episenternya berada di selatan pulau tersebut. pergeseran minimum sebesar $460 \mathrm{~m}$.

a)

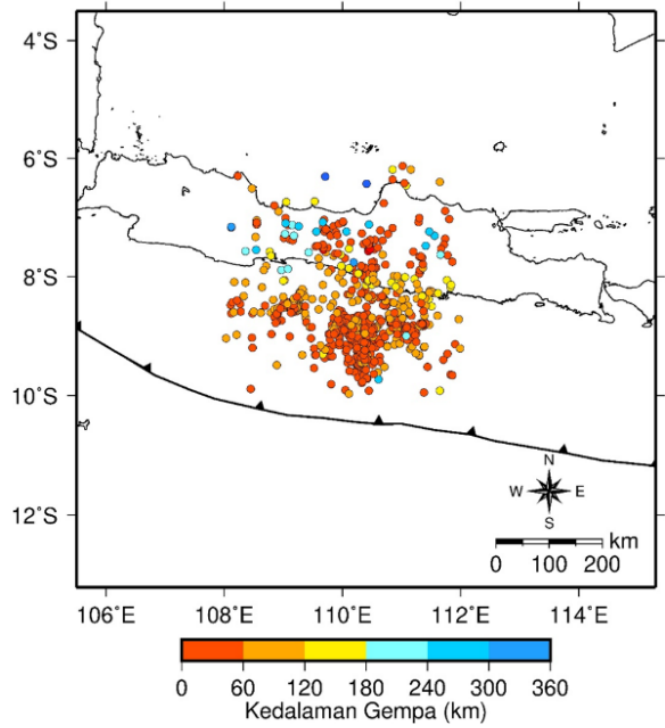

b)

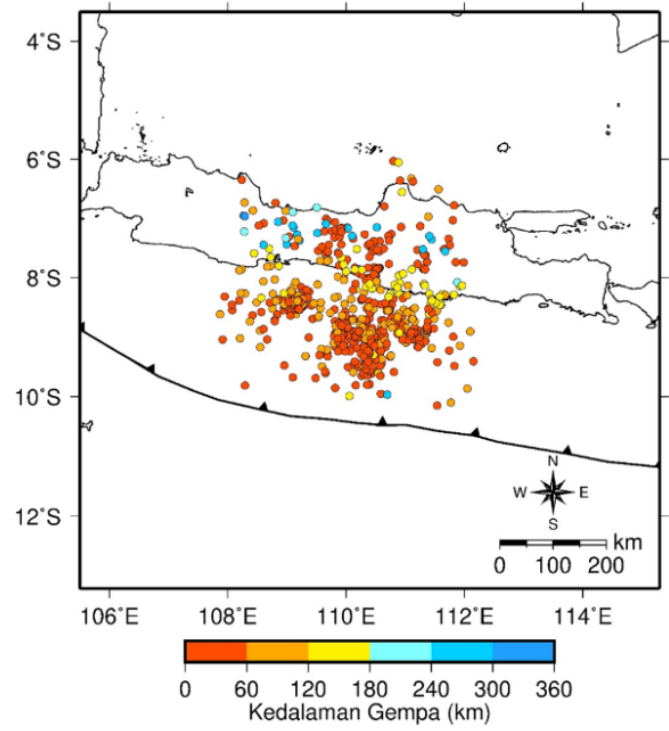

Gambar 4. Distribusi episenter gempa yang direkam oleh empat jaringan seismik sebelum (a) dan sesudah (b) dilakukan relokasi hiposenter dengan model kecepatan 3-D.

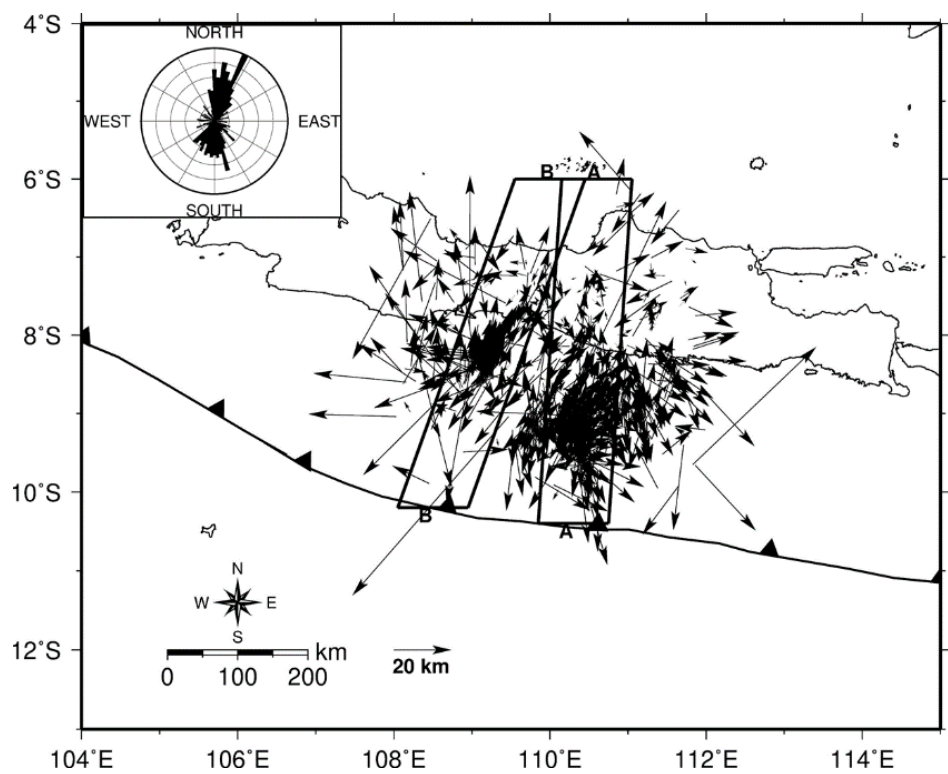

Gambar 5. Vektor pergeseran posisi episenter relatif terhadap posisi awal sebelum dilakukan relokasi hiposenter dan diagram mawar (gambar inset) setelah dilakukan relokasi hiposenter dengan model kecepatan 3-D pada empat jaringan seismik. Kedua kotak menunjukkan lokasi penampang vertikal untuk A-A' dan B-B' yang ditunjukkan di gambar 6 dan 8 dengan lebar sebesar $100 \mathrm{~km}$. 
Gambar 6 menunjukkan penampang arah A-A' yang memotong Zona Subduksi, Sesar Opak dan Gunung Merapi. Pada zona subduksi, hasil relokasi dengan model kecepatan 3-D menunjukkan hiposenter melingkupi model slab 1.0 [23]. Sementara itu, hasil relokasi pada model kecepatan 1-D menunjukkan posisi hiposenter mayoritas berada di bawah model slab tersebut. Hal ini disebabkan karena model kecepatan 1-D yang digunakan hanya memperhitungkan perbedaan kecepatan secara vertikal saja sementara kecepatan secara lateral dianggap sama. Adapun model kecepatan 3-D memperhitungkan perbedaaan baik pada arah vertikal maupun lateral sehingga pola slab yang diakibatkan oleh variasi kecepatan material arah vertikal dan lateral lebih terakomodasi dibandingkan dengan model kecepatan 1-D. Fitur double seismic zone yang berada pada kedalaman 40 sampai $\sim 150 \mathrm{~km}$ tidak bisa terdeteksi dengan jelas sebagaimana pada studi terdahulu [5]. Gempa-gempa volcano tectonic (VT) yang berkaitan dengan aktivitas magma di bawah Gunung Merapi juga terlihat lebih jelas setelah dilakukan relokasi hiposenter dengan model kecepatan 3-D. Jumlah gempa di bawah gunung api tersebut tidak terlalu banyak karena periode pemasangan seismometer DOMERAPI tidak bertepatan dengan aktivitas erupsi di Gunung tersebut.

Gambar 7 memperlihatkan aktivitas seismik di timur Sesar Opak selama periode perekaman proyek DOMERAPI. Gempagempa tersebut kemungkinan besar masih berkaitan dengan gempa besar yang terjadi pada tanggal 26 Mei tahun 2006. Gempa tersebut memiliki mekanisme sesar mendatar sinistral dengan magnitudo sebesar $6,3 \mathrm{Mw}$ $[24,25]$. Hasil pengamatan synthetic aperture radar (SAR) interferometry menunjukkan gempa besar tersebut terjadi pada hidden fault karena tidak terlihatnya penampakan perubahan geomorfologi yang signfikan ketika sebelum dan sesudah terjadinya gempa [26]. Kondisi geologi di sekitar episenter gempa yang dilingkupi oleh sedimen yang sangat tebal bisa menjadi penyebab tidak adanya kenampakan sesar di permukaan [27]. Gempa-gempa yang terjadi di sesar aktif biasanya terjadi di bagian basement kerak benua. Daerah yang terlingkupi oleh sedimen sangat tebal menyebabkan slip yang terbentuk akibat gempa tidak muncul sampai ke permukaan.

Penampang vertikal arah barat-timur menunjukkan mayoritas gempa berada pada kedalaman kurang dari $25 \mathrm{~km}$. Hal ini berkorelasi dengan studi receiver function di daerah tersebut yang menunjukkan kedalaman maksimal kerak bumi berada di sekitar $30 \mathrm{~km}$ [28]. Episenter gempa tahun 2006 posisinya sejajar dengan episenter gempa yang terekam oleh jaringan seismik DOMERAPI. Penampang vertikal X-X' yang ditunjukkan oleh Gambar 7 memperlihatkan bahwa gempa-gempa tersebut berasal dari satu bidang sehingga arah dip Sesar Opak ke arah timur. Walaupun demikian, penelitian lebih lanjut dengan metode yang berbeda perlu dilakukan untuk lebih memastikannya. 
a)

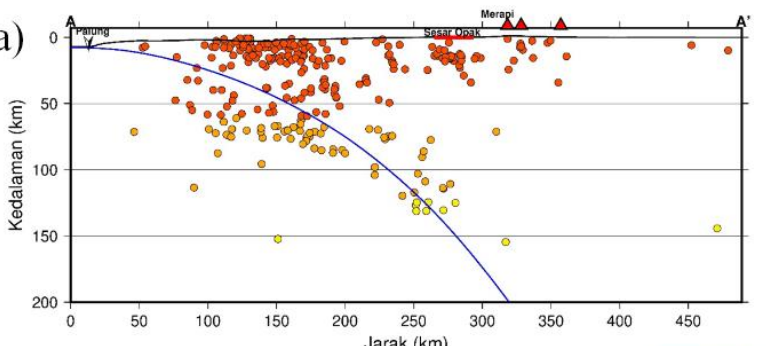

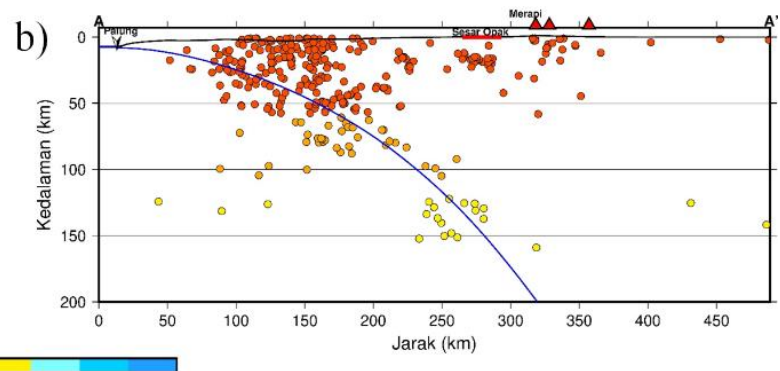

Gambar 6. Penampang vertikal arah A-A' sebelum (a) dan sesudah (b) relokasi hiposenter dengan model kecepatan 3-D pada jaringan seismik DOMERAPI dan BMKG. Garis biru menunjukkan slab 1.0 [23].

a)
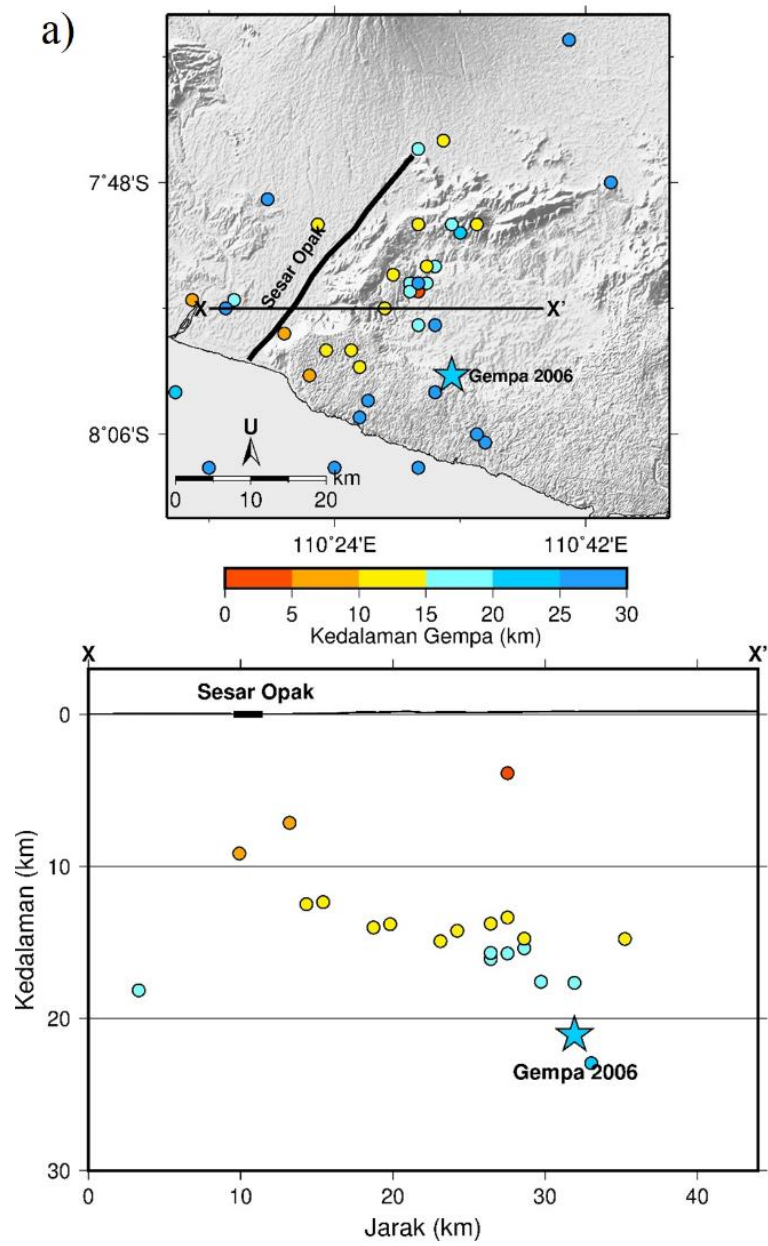

b)
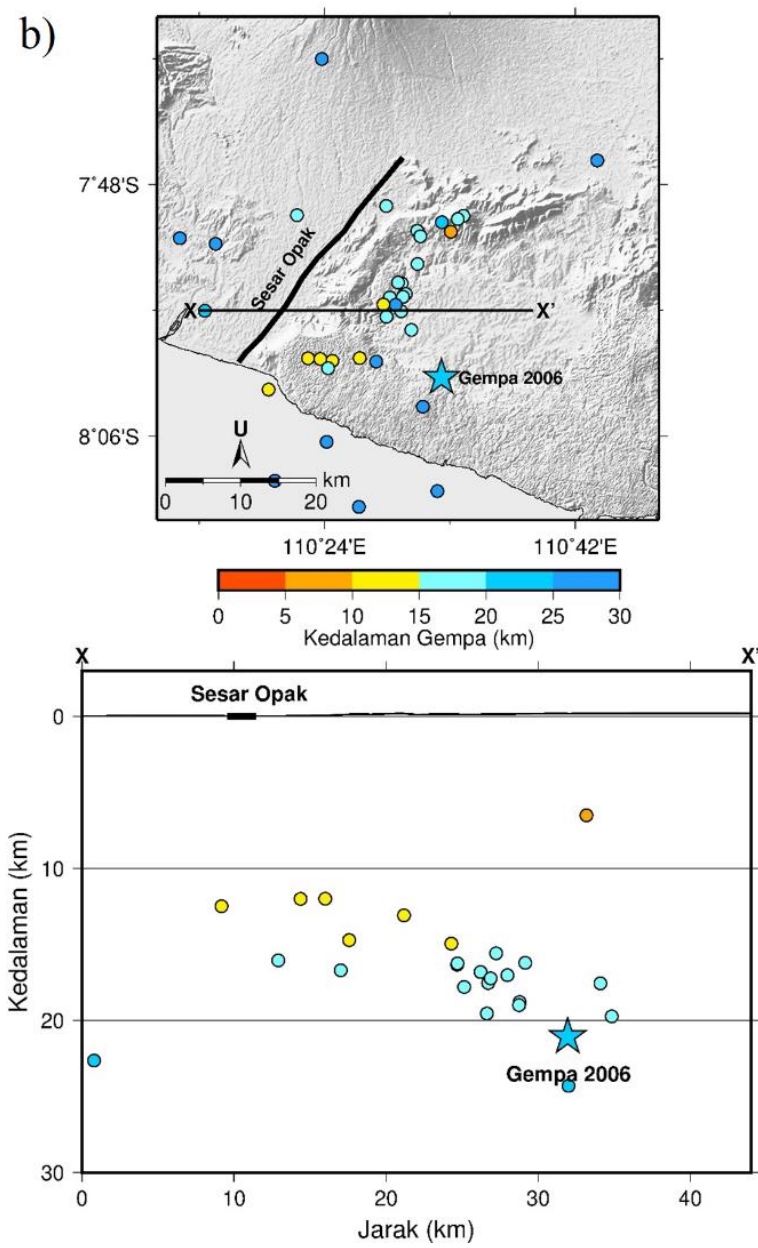

Gambar 7. Seismisitas di sekitar Sesar Opak (atas) dan penampang vertikal arah barat-timur (bawah) sebelum (a) dan sesudah (b) relokasi hiposenter dengan model kecepatan 3-D pada empat jaringan seismik dimana mayoritas gempanya direkam oleh jaringan seismik DOMERAPI. Gempa 2006 diambil dari katalog gempa global CMT [24]. Jarak gempa ke garis penampang X-X' maksimum sebesar $0,25^{\circ}$.

Gambar 8 menunjukkan penampang vertikal arah B-B' sebelum dan sesudah relokasi hiposenter dengan model kecepatan 3-D. Distribusi hiposenter tersebut menunjukkan tunjaman slab yang cukup tajam. Tunjaman slab yang tajam kemungkinan besar berkaitan dengan usia slab yang relatif tua [29]. Pada kedalaman kurang dari $30 \mathrm{~km}$ terdapat sebuah cluster gempa yang terpisah dengan bagian 
bawahnya. Cluster tersebut kemungkinan besar berkaitan dengan struktur backthrust. Sesar backthrust pada penampang tersebut terjadi di kompleks prisma akresi. Struktur sesar backthrust memiliki dip atau kemiringan bidang sesar yang berlawanan arah dengan kemiringan bidang main thrust dan terbentuk pada anjakan (thrust) [30]. Arah dip main thrust di zona subduksi berarah ke utara sebagaimana arah gaya tektonik utama di Pulau Jawa.
Pada kedalaman 50 hingga $100 \mathrm{~km}$ terdapat sebuah cluster gempa yang berada di bawah garis slab, tepatnya pada peralihan lengkungan slab dari landai menjadi curam. Cluster ini merupakan gempa-gempa intraslab di dalam lempeng samudera. Sebaran gempa-gempa ini membentuk garis miring dengan dip sejajar dip subduksi tetapi lebih curam. Gempa-gempa ini disebabkan oleh gaya tarikan pada lempeng (slab pull) akibat gaya beratnya sendiri [31].

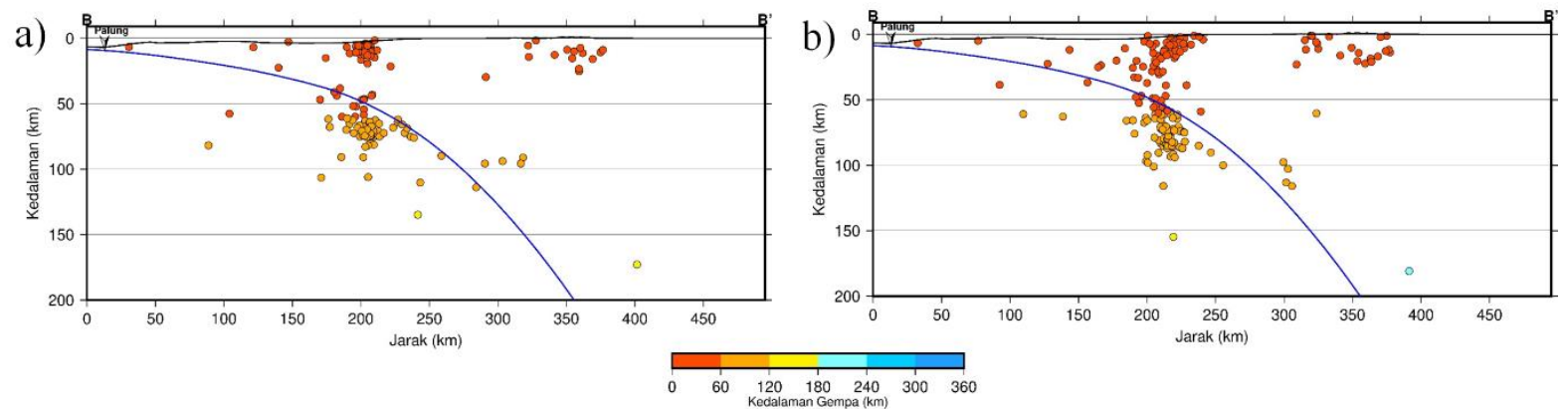

Gambar 8. Penampang vertikal arah B-B' sebelum (a) dan sesudah (b) relokasi hiposenter dengan model kecepatan 3-D pada empat jaringan seismik. Garis biru menunjukkan slab 1.0 [23].

\section{KESIMPULAN}

Hasil relokasi hiposenter menggunakan model kecepatan 3-D memperlihatkan hasil yang lebih baik dibandingkan dengan model kecepatan 1-D. Secara statistik keunggulan model kecepatan 3-D ditunjukkan dari distribusi RMS residual time yang mendekati nol jauh lebih banyak. Secara seismotektonik fitur-fitur tektonik menjadi terlihat lebih jelas. Hal ini ditunjukkan dengan sejumlah zona pembangkit gempa seperti Sesar Opak, zona backthrust, dan zona intraslab selain zona subduksi itu sendiri. Hasil penelitian ini sangat berguna sebagai katalog gempa presisi pada studi tektonik tingkat lanjut seperti studi seismic hazard assessment untuk keperluan perencanaan pembangunan.

\section{UCAPAN TERIMA KASIH}

Kami mengucapkan terima kasih kepada Institut de Recherche pour le Dèveloppement (IRD), Prancis yang telah membiayai proyek DOMERAPI dan BMKG serta BPPTKG yang telah memberikan akses data waveform gempa pada stasiun-stasiun seismik yang digunakan. Terima kasih juga kami sampaikan kepada German Research Centre for Geosciences (GFZ) yang telah mengizinkan penggunaan data katalog gempa jaringan seismik MERAMEX. Gambargambar pada tulisan ini diplot menggunakan program Generic Mapping Tools [32]. 


\section{DAFTAR PUSTAKA}

[1] A. P. Cahyaningrum, A. D. Nugraha, dan N. T. Puspito, "Earthquake Hypocenter Relocation Using Double Difference Method in East Java and Surrounding Areas," in AIP Conference Proceedings, vol. 1658, p. 030021, 2015.

[2] A. D. Nugraha, H. A. Shiddiqi, S. Widiyantoro, C. H. Thurber, J. D. Pesicek, H. Zhang, S. H. Wiyono, M. Ramdhan, dan M. Irsyam, "Hypocenter Relocation along the Sunda Arc in Indonesia, Using a 3D Seismic-Velocity Model," Seismological Research Letters, vol. 89, no. 2A, pp. 603-612, 2018.

[3] M. Ramdhan dan A. D. Nugraha, "Study of Seismicity Around Toba Area Based on Relocation Hypocenter Result from BMKG Catalogue" in Padjadjaran International Physics Symposium 2013 (PIPS-2013): Contribution of Physics on Environmental and Energy Conservations, vol. 1554, pp. 242-244, 2013.

[4] A. Sabtaji dan A. D. Nugraha, "1-D Seismic Velocity Model and Hypocenter Relocation Using Double Difference Method Around West Papua Region," in AIP Conference Proceedings, vol. 1658, 2015.

[5] I. Koulakov, M. Bohm, G. Asch, B. -G. Lühr, A. Manzanares, K. S. Brotopuspito, P. Fauzi, M. A. Purbawinata, N. T. Puspito, A. Ratdomopurbo, H. Kopp, W. Rabbel, E. Shevkunova, "P and S Velocity Structure of the Crust and The Upper Mantle Beneath Central Java from Local Tomography Inversion," Journal of Geophysical Research: Solid Earth, vol. 112, no. B8, 2007.

[6] D. Wagner, I. Koulakov, W. Rabbel, B. -G. Luehr, A. Wittwer, H. Kopp, M. Bohm, G. Asch, dan MERAMEX Scientists, "Joint Inversion of Active and Passive Seismic Data in Central Java," Geophysical Journal International, vol. 170, no. 2, pp. 923-932, 2007.

[7] S. Rohadi, S. Widiyantoro, A. Nugraha, dan Masturyono, "Tomographic imaging of $\mathrm{P}$ and $\mathrm{S}$ Wave Velocity Structure Beneath Central Java, Indonesia: Joint Inversion of The MERAMEX and MCGA Earthquake Data," International Journal of Tomography \& Simulation ${ }^{T M}$, vol. 24, no. 3, pp. 1-16, 2013.

[8] A. Ratdomopurbo dan G. Poupinet, "An Overview of The Seismicity of Merapi Volcano (Java, Indonesia), 1983-1994," Journal of Volcanology and Geothermal Research, vol. 100, no. 1-4, pp. 193-214, Jul. 2000, doi: 10.1016/S0377-0273(00)00137-2.

[9] Surono dkk., "The 2010 Explosive Eruption of Java's Merapi Volcano-A '100-year' Event," Journal of Volcanology and Geothermal Research, vol. 241-242, pp. 121-135, Oct. 2012, doi: 10.1016/j.jvolgeores.2012.06.018.
[10] C. Haberland, M. Bohm, dan G. Asch, "Accretionary Nature of The Crust of Central and East Java (Indonesia) Revealed by Local Earthquake Travel-time Tomography," Journal of Asian Earth Sciences, vol. 96, pp. 287-295, Dec. 2014, doi: 10.1016/j.jseaes.2014.09.019.

[11] S. Widiyantoro, M. Ramdhan, J. -P. Métaxian, P. R. Cummins, C. Martel, S. Erdmann, A. D. Nugraha, A. Budi-Santoso, A. Laurin dan A. A. Fahmi, "Seismic Imaging and Petrology Explain Highly Explosive Eruptions of Merapi Volcano, Indonesia," Scientific Reports, vol. 8, no. 1, p. 13656, Sep. 2018, doi: 10.1038/s41598-01831293-w.

[12] M. Ramdhan, S. Widiyantoro, A. D. Nugraha, J. -P. Métaxian, N. Rawlinson, A. Saepuloh, S. Kristyawan, A. S. Sembiring, A. B. Santoso, A. Laurin, dan A. A. Fahmi., "Detailed Seismic Imaging of Merapi Volcano, Indonesia, from Local Earthquake Travel-time Tomography," Journal of Asian Earth Sciences, vol. 177, pp. 134-145, Jun. 2019, doi: 10.1016/j.jseaes.2019.03.018.

[13] M. Ramdhan, S. Kristyawan, A. S. Sembiring, D. Daryono, dan P. Priyobudi, "Struktur Kecepatan Seismik di Bawah Gunung Merapi dan Sekitarnya Berdasarkan Studi Tomografi Seismik Waktu Tempuh," RISET Geologi dan Pertambangan, vol. 29, no. 2, Dec. 2019, doi: 10.14203/risetgeotam2019.v29.1047.

[14] M. Ramdhan, S. Widiyantoro, A. D. Nugraha, J. -P Métaxian, A. Saepuloh, S. Kristyawan, A. S. Sembiring, A. B. Santoso, A. Laurin, dan A. A. Fahmi, "Relocation of Hypocenters from DOMERAPI and BMKG Networks: A Preliminary Result from DOMERAPI Project," Earthquake Science, vol. 30, no. 2, pp. 67-79, 2017.

[15] M. Ramdhan, A. D. Nugraha, S. Widiyantoro, J.P. Métaxian, dan A. A. Valencia, "Earthquake Location Determination Using Data from DOMERAPI and BMKG Seismic Networks: A Preliminary Result of DOMERAPI Project," in 4th International Symposium on Earthquake and Disaster Mitigation 2014 (ISEDM 2014), 2015, vol. 1658 , p. 030007.

[16] F. Waldhauser dan W. L. Ellsworth, "A doubledifference Earthquake Location Algorithm: Method and Application to The Northern Hayward Fault, California," Bulletin of the Seismological Society of America, vol. 90, no. 6, pp. 1353-1368, 2000.

[17] F. Waldhauser, "HypoDD: A Computer Program to Compute Double-difference Earthquake Location," US Geol. Surv. Openfile report, pp. 01-113, 2001.

[18] J. R. Evans, D. Eberhart-Phillips, dan C. Thurber, "User's Manual for SIMULPS12 for Imaging Vp and $\mathrm{Vp} / \mathrm{Vs}$; a Derivative of The" Thurber" 
tomographic inversion SIMUL3 for local earthquakes and explosions," US Geological Survey, 1994.

[19] C. Thurber, Local Earthquake Tomography: Velocities and $\mathrm{Vp} / \mathrm{Vs}$-theory in Seismic Tomography: Theory and Practice pp. 563-583 eds Iyer HM, Hirahara K. Chapman \& Hall London, 1993.

[20] C. Thurber dan D. Eberhart-Phillips, "Local Earthquake Tomography with Flexible Gridding," Computers \& Geosciences, vol. 25, no. 7, pp. 809-818, 1999.

[21] C. C. Paige dan M. A. Saunders, "LSQR: An Algorithm for Sparse Linear Equations and Sparse Least Squares," ACM Transactions on Mathematical Software, vol. 8, no. 1, pp. 43-71, 1982.

[22] J. Pesicek, C. Thurber, H. Zhang, H. DeShon, E. Engdahl, dan S. Widiyantoro, "Teleseismic Double-difference Relocation of Earthquakes Along the Sumatra-Andaman Subduction Zone Using a 3-D Model," Journal of Geophysical Research: Solid Earth, vol. 115, no. B10, 2010.

[23] G. P. Hayes, D. J. Wald, dan R. L. Johnson, "Slab1. 0: A three-dimensional Model of Global Subduction Zone Geometries," Journal of Geophysical Research: Solid Earth, vol. 117, no. B1, 2012.

[24] Global CMT, "Global Centroid Moment Tensor Project." http://www.globalcmt.org/ (accessed Nov. 07, 2016).

[25] M. Nakano, H Kumagai, K. Miyakawa, T. Yamashina, H Inoue, M. Ishida, S. Aoi, N. Morikawa, dan P Harjadi, "Source Estimates of The May 2006 Java Earthquake," Eos, Transactions American Geophysical Union, vol. 87, no. 45, pp. 493-494, Nov. 2006, doi: 10.1029/2006EO45 0002.

[26] T. Tsuji, K. Yamamoto, T. Matsuoka, Y. Yamada, K. Onishi, A. Bahar, I. Meilano, dan H.
Z. Abidin, "Earthquake Fault of the 26 May 2006 Yogyakarta Earthquake Observed by SAR Interferometry," Earth, Planets and Space, vol. 61, no. 7, p. e29, Aug. 2009, doi: 10.1186/BF033 53189.

[27] H. R. Smyth, R. Hall, dan G. J. Nichols, "Cenozoic Volcanic Arc History of East Java, Indonesia: The stratigraphic Record of Eruptions on an Active Continental Margin," in Special Paper 436: Formation and Applications of the Sedimentary Record in Arc Collision Zones, vol. 436, Geological Society of America, 2008, pp. 199-222.

[28] I. Wölbern dan G. Rümpker, "Crustal Thickness Beneath Central and East Java (Indonesia) Inferred from P Receiver Functions," Journal of Asian Earth Sciences, vol. 115, pp. 69-79, Jan. 2016, doi: 10.1016/j.jseaes.2015.09.001.

[29] J. D. Pesicek, C. H. Thurber, S. Widiyantoro, E. R. Engdahl, dan H. R. DeShon, "Complex Slab Subduction Beneath Northern Sumatra," Geophys. Res. Lett., vol. 35, no. 20, p. L20303, Oct. 2008, doi: 10.1029/2008GL035262.

[30] S. Xu, E. Fukuyama, Y. Ben-Zion, dan J.-P. Ampuero, "Dynamic Rupture Activation of Backthrust Fault Branching," Tectonophysics, vol. 644-645, pp. 161-183, Mar. 2015, doi: 10.1016/j.tecto.2015.01.011.

[31] S. Lallemand, A. Heuret, dan D. Boutelier, "On the Relationships Between Slab Dip, Back-arc Stress, Upper Plate Absolute Motion, and Crustal Nature in Subduction Zones," Geochemistry, Geophysics, Geosystems, vol. 6, no. 9, 2005, doi: 10.1029/2005GC000917.

[32] P. Wessel dan W. H. Smith, "New, Improved Version of Generic Mapping Tools Released," Eos, Transactions American Geophysical Union, vol. 79, no. 47, pp. 579, 1998. 